\title{
Yield Performance of Six Local Aromatic Rice Cultivars
}

\author{
Nahida Islam ${ }^{1}$, Md. Yamin Kabir ${ }^{2}$, Sanjoy Kumar Adhikary ${ }^{3}$, \\ Md. Sarwar Jahan ${ }^{4}$ \\ ${ }^{I}$ (Additional Agriculture Officer, Department of Agricultural Extension, Ministry of Agriculture, Bangladesh) \\ ${ }_{2}^{2}$ (Associate Professor, Agrotechnology Discipline, Khulna University, Bangladesh) \\ ${ }^{3,4}$ (Professor, Agrotechnology Discipline, Khulna University, Bangladesh)
}

\begin{abstract}
An experiment was conducted to evaluate the performance of local aromatic rice cultivars viz. Kalijira, Khaskani, Kachra, Raniselute, Morichsail and Badshabhog. The rice cultivars varied considerably in terms of crop growth characteristics as well as yield and yield contributing characters. The highest plant height $(116.00 \mathrm{~cm})$ was found in the variety Morichsail and the lowest in the variety Khaskani. Number of filled grains panicle $e^{-1}$ was found highest (100) with the variety Khaskani and the lowest was recorded in the variety Raniselute. Raniselute produced the highest 1000-grain weight (32.09 g) and the lowest (13.32 g) was recorded from the variety Kalijira. The variety Morichsail produced the highest grain yield $\left(2.53 \mathrm{th} \mathrm{h}^{-1}\right)$ followed by

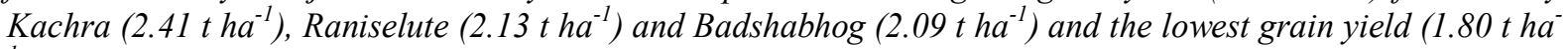
$\left.{ }^{1}\right)$ was obtained from Kalijira. The results of various characters studied in the experiments suggested that some good characters exist in local aromatic rice cultivars which can be exploited through breeding.
\end{abstract}

Keywords: Aromatic rice, growth parameters, yield contributing characters, yield

\section{Introduction}

Aromatic rice contributes a small but an important sub-group of rice. These rices are rated best in quality and fetch much higher price in international market. These rices have long been popular in the orient and are now becoming more popular in Middle East, Europe and the United States. Most of the aromatic rice cultivars in Bangladesh are of traditional type, photoperiod-sensitive and are grown during Aman season in the rainfed low land ecosystem [1]. Baqui et al. [2] revealed that among the aromatic rice cultivars, Chinigura was the predominant one that covered more than $70 \%$ farms in the northern districts of Naogaon and Dinajpur. In these districts, $30 \%$ of the rice lands were covered by aromatic rice cultivars during Aman season. Islam et al. [3] observed that the yield of aromatic rice was low (1.5 to $\left.2.0 \mathrm{t} \mathrm{ha}^{-1}\right)$ but its high price and low cost of cultivation generated higher profit margins compared to other rice cultivars. There are hardly 3,000-5,000 local cultivars under cultivation in Bangladesh [4]. The rapid rate of extinction of indigenous cultivars of local rice points to the danger of narrowing genetic base.

For the development of high yielding aromatic rice varieties our indigenous aromatic rice cultivars may play a vital role as parent material because they are most adaptive to our environment. Although some research works were done and a few high yielding aromatic rice varieties were released by BRRI, our indigenous cultivars were given less attention and their yielding ability was not studied well. Therefore, the present study was undertaken to explore the yielding ability of six indigenous aromatic rice cultivars.

\section{Materials and Methods}

The experiment was conducted at the Field Laboratory of Agrotechnology Discipline, Khulna University, Khulna during the Aman season of 2006 with six indigenous aromatic rice cultivars namely Kalijira $\left(\mathrm{V}_{1}\right)$, Khaskani $\left(\mathrm{V}_{2}\right)$, Kachra $\left(\mathrm{V}_{3}\right)$, Raniselute $\left(\mathrm{V}_{4}\right)$, Morichsail $\left(\mathrm{V}_{5}\right)$ and Badshabhog $\left(\mathrm{V}_{6}\right)$ as six treatments following Randomized Complete Block Design with three replications.

Data collection: Data were collected on different growth parameters such as plant height, tiller number and dry matter accumulation and yield contributing characters viz. number of effective tillers per hill, length of panicle, number of grains per panicle, 1000-grain weight, grain yield, straw yield, biological yield, harvest index and grain weight.

Statistical analysis: The data were analyzed by MSTAT-C program and treatment means were compared using Duncan's Multiple Range Test [5]. Functional relationships were determined among different growth and yield parameters using simple regression analysis.

\section{Results and Discussion}

3.1 Growth parameters

Plant height: Plant height increased progressively reaching a maximum or peak at 78 days after transplanting (DAT), thereafter it nearly reached a plateau (Fig. 1). The highest plant height $(116.00 \mathrm{~cm})$ was found in the 
variety Morichsail and the lowest $(63.70 \mathrm{~cm})$ in Khaskani. Variation in plant height might be due to the differences in their genetic make up. These results were in consistent to those of Sawant et al. [6], Shamsuddin et al. [7], Hossain et al. [8] and Khatun [9] who also observed variable plant heights among the varieties.

Tiller dynamics: Tiller production was affected markedly by the variety. Tiller number in most of the treatments increased almost exponentially upto 78 DAT and after that a gradual decline in tiller number was noticed and before harvest it reached a plateau (Fig. 2). The maximum number of tillers $\mathrm{m}^{-2}(404.20)$ was observed in the variety Kalijira and the minimum (108.90) was recorded in the variety Khaskani. Variation in tiller number might be due to the differences in their genetic make up. Similar results was also reported by Ramasamy et al. [10] who stated that number of tillers $\mathrm{m}^{-2}$ differed due to varietal variation.

Dry matter accumulation: Results revealed that dry matter (DM) accumulation over time varied considerably due to variety (Fig. 3). Among different Days After Transplanting (DAT), Kachra produced the highest dry matter $\left(1420.7 \mathrm{~g} \mathrm{~m}^{-2}\right)$ and Kalijira produced the lowest dry matter $\left(1105.7 \mathrm{~g} \mathrm{~m}^{-2}\right)$ at $92 \mathrm{DAT}$. These results are supported by the result of Vergera et al. [11] who reported that dry matter accumulation increased with time and the initial increase was slow then it was accelerated.

\subsection{Varietal differences of yield and yield contributing characters}

Effective tillers per hill: The highest number of effective tillers hill ${ }^{-1}(13.0)$ was produced by Kalijira and the lowest number of effective tillers hill ${ }^{-1}$ (7.13) was observed in Morichasail (Table 1). The reason of difference in effective tillers hill ${ }^{-1}$ is the genetic makeup of the variety, which is primarily influenced by heredity. This result was supported by Chowdhury et al. [12] and Anonymous [13] who stated that effective tillers hill ${ }^{-1}$ varied with the variety.

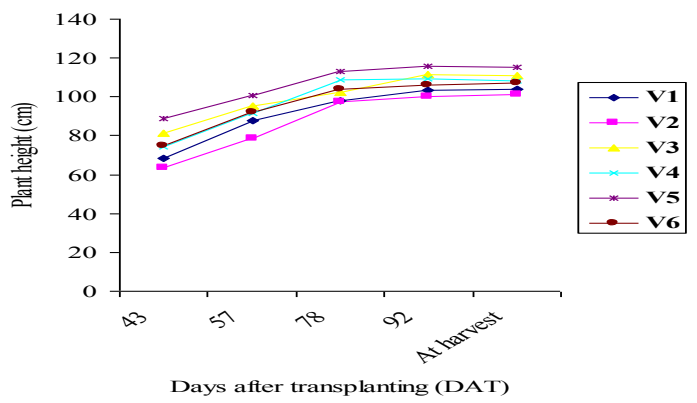

Fig. 1. Plant height over time as found in different aromatic rice cultivars.

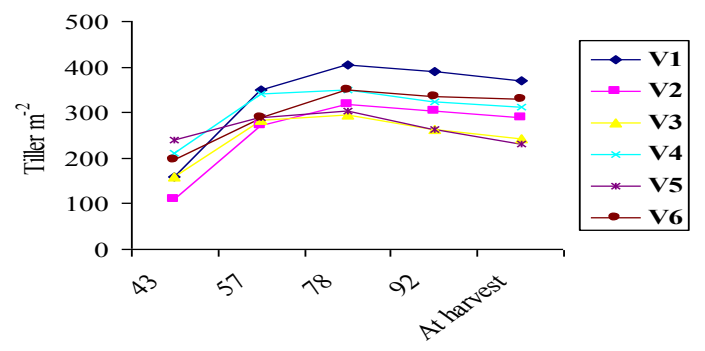

Days after transplanting (DAT)

Fig. 2. Tiller dynamics over time as observed in different aromatic rice cultivars.

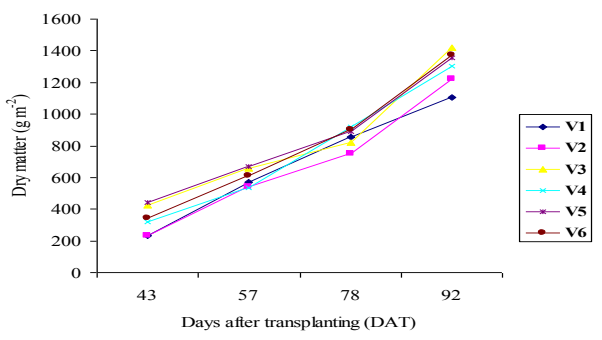

Fig. 3. Total dry matter production as recorded in different aromatic rice cultivars.

$\mathrm{V}_{1}=$ Kalijira, $\mathrm{V}_{2}=$ Khaskani, $\mathrm{V}_{3}=$ Kachra, $\mathrm{V}_{4}=$ Raniselute, $\mathrm{V}_{5}=$ Morichsail and $\mathrm{V}_{6}=$ Badshabhog 
Panicle length: Panicle length recorded was the highest $(23.25 \mathrm{~cm})$ in the variety Morichsail and the variety Kalijira produced lowest panicle length $(20.03 \mathrm{~cm}$ ) (Table 1). Similar result was also recorded by Idris and Matin [14] and Anonymous [15] who reported that panicle length influenced by variety. The variation as assessed might be mainly due to genetic background of the variety. A simple linear regression using panicle length as independent variable and yield as dependent variable showed a positive but non significant relationship (Fig. 4). The value of $\mathrm{R}^{2}(0.59)$ indicates that about $60 \%$ variation in yield could be explained by the variation in panicle length.

Table 1. Varietal differences in yield and yield attributes of six local aromatic rice cultivars

\begin{tabular}{|c|c|c|c|c|c|c|c|c|}
\hline Variety & $\begin{array}{l}\text { Effective } \\
\text { tillers hill }^{-1}\end{array}$ & $\begin{array}{l}\text { Panicle } \\
\text { length }(\mathrm{cm})\end{array}$ & $\begin{array}{l}\text { Filled } \\
\text { grains } \\
\text { panicle }{ }^{-1} \\
(\text { No. })\end{array}$ & $\begin{array}{l}\text { Unfilled } \\
\text { grains } \\
\text { panicle } \\
\text { (No.) }\end{array}$ & $\begin{array}{l}1000- \\
\text { grain } \\
\text { weight } \\
(\mathrm{g})\end{array}$ & $\begin{array}{l}\text { Grain } \\
\text { yield } \\
\left(\mathrm{t} \mathrm{ha}^{-1}\right)\end{array}$ & $\begin{array}{l}\text { Biological } \\
\text { Yield } \\
\left(\mathrm{t} \mathrm{ha}^{-1}\right)\end{array}$ & $\begin{array}{l}\text { Harvest } \\
\text { index }(\%)\end{array}$ \\
\hline $\mathrm{V}_{1}$ & $13.0 \mathrm{a}$ & $20.03 c$ & $67.69 b c$ & $21.17 b c$ & $13.32 \mathrm{c}$ & $1.38 \mathrm{~b}$ & $3.87 \mathrm{~b}$ & 35.7 \\
\hline $\mathrm{V}_{2}$ & $11.40 \mathrm{ab}$ & $22.01 \mathrm{abc}$ & $100.0 \mathrm{a}$ & $38.88 \mathrm{a}$ & $14.77 \mathrm{c}$ & $1.63 b$ & $4.52 \mathrm{~b}$ & 36.06 \\
\hline $\mathrm{V}_{3}$ & $8.26 \mathrm{bc}$ & $22.91 \mathrm{ab}$ & $51.61 \mathrm{~cd}$ & $12.0 \mathrm{c}$ & $31.69 \mathrm{a}$ & $2.41 \mathrm{a}$ & $9.46 \mathrm{a}$ & 25.48 \\
\hline $\mathrm{V}_{4}$ & $9.40 \mathrm{abc}$ & $21.52 \mathrm{abc}$ & $42.20 \mathrm{~d}$ & $11.96 \mathrm{c}$ & $32.09 \mathrm{a}$ & $2.13 \mathrm{a}$ & $6.69 \mathrm{ab}$ & 31.84 \\
\hline $\mathrm{V}_{5}$ & $7.13 \mathrm{c}$ & $23.25 \mathrm{a}$ & $57.30 \mathrm{~cd}$ & $11.17 \mathrm{c}$ & $31.58 \mathrm{a}$ & $2.53 \mathrm{a}$ & $8.80 \mathrm{a}$ & 28.75 \\
\hline $\mathrm{V}_{6}$ & $11.80 \mathrm{ab}$ & $20.74 b c$ & $81.89 \mathrm{ab}$ & $32.93 \mathrm{ab}$ & $20.19 b$ & $2.09 \mathrm{a}$ & $6.61 \mathrm{ab}$ & 31.62 \\
\hline $\begin{array}{l}\text { Level of } \\
\text { Significance }\end{array}$ & 0.05 & 0.01 & 0.01 & 0.01 & 0.01 & 0.01 & 0.01 & NS \\
\hline CV (\%) & 18.87 & 4.09 & 13.48 & 28.75 & 6.77 & 12.61 & 25 & 13.08 \\
\hline
\end{tabular}

Filled grains per panicle: Results presented in the Table 1 showed that number of filled grains panicle ${ }^{-1}$ was found highest (100) with the variety Khaskani and the lowest was recorded with the variety Raniselute. Anonymous [16] reported that the number of filled grains panicle ${ }^{-1}$ influenced significantly due to variety. The results were also supported by Singh and Gangwer [17].

Unfilled grains per panicle: Among the undesirable traits, number of unfilled grains panicle ${ }^{-1}$ was important one and played a vital role in yield reduction. Effect of variety on the number of unfilled grains panicle ${ }^{-1}$ was highly significant. Morichsail produced the lowest number of unfilled grains panicle $e^{-1}(11.17)$ which contributed highest grain yield of that variety. This variation in number of unfilled grains panicle ${ }^{-1}$ might be due to genetic characteristics of the varieties [12], [15]. A simple linear regression using unfilled grains as independent variable and yield as dependent variable showed a negative relationship suggesting that as the proportion of unfilled grains increased, yield of the varieties decreased.

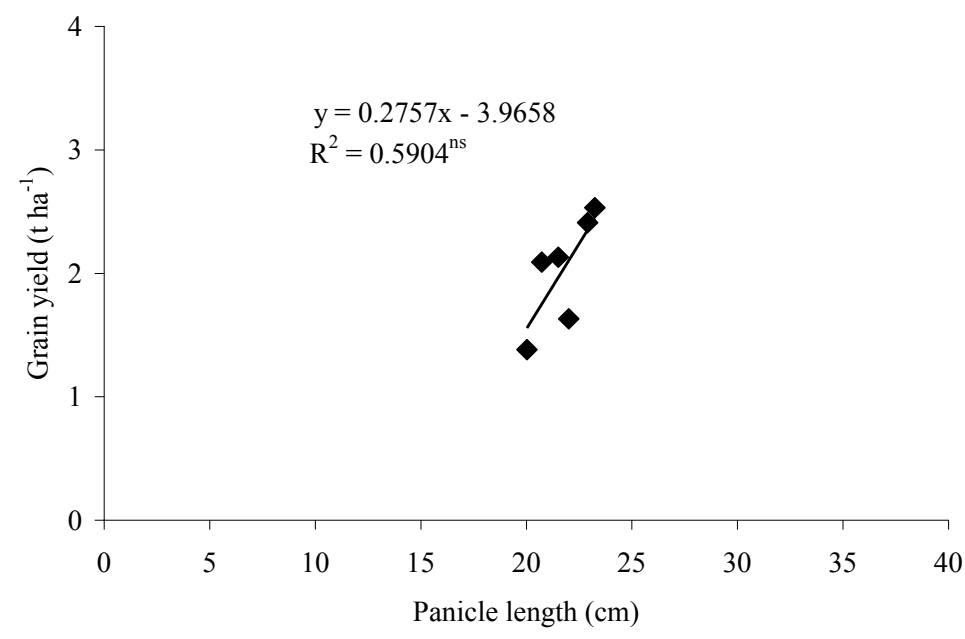

Fig. 4. Functional relationship between panicle length and grain yield in aromatic rice cultivars.

1000-grain weight: Variety differed significantly among them regarding weight of 1000-grains (Table 1) and the highest 1000 -grain weight ( $32.09 \mathrm{~g}$ ) was produced by the variety Raniselute, might be due to its larger grain size and lowest 1000 -grain weight (13.32 g) was recorded from the variety Kalijira for its smaller grain size. The variety Kalijira was also mentioned as having lowest 1000-grain weight by Khatun [9] and Sarkar [18]. From the Fig. 6, it was observed that grain yield has significant positive relationship with 1000 -grain weight. 


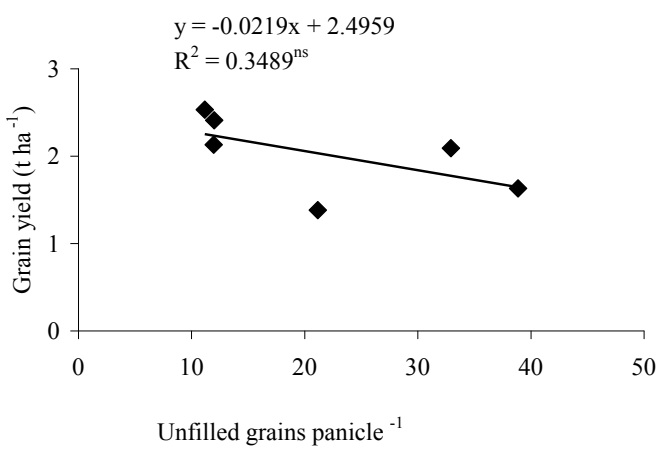

Fig. 5. Functional relationship between grain yield and unfilled grains panicle ${ }^{-1}$ in aromatic rice.

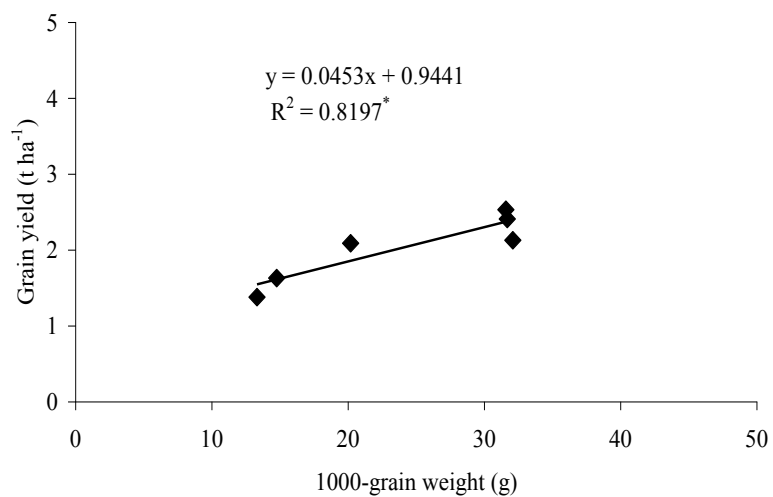

Fig. 6. Functional relationship between grain yield and 1000-grain weight of aromatic rice.

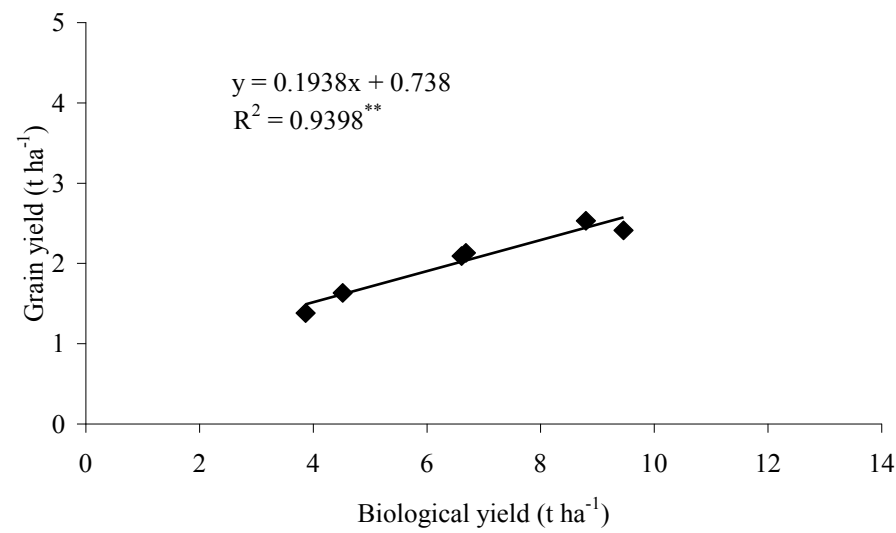

Fig. 7. Functional relationship between grain yield and biological yield of aromatic rice.

Grain Yield: Grain yield of rice mainly depends on the number of effective tillers per unit area, panicle length, filled grains panicle ${ }^{-1}$ and 1000-grain weight. Results shown in the Table 1 presented that the grain yield differed significantly among the varieties. The variety Morichsail produced the highest grain yield $\left(2.53 \mathrm{tha}^{-1}\right)$ and the lowest yield $\left(1.38 \mathrm{t} \mathrm{ha}^{-1}\right)$ was obtained from Kalijira. Similar yielding trend i.e. 1.92 to $2.56 \mathrm{t} \mathrm{ha}^{-1}$ was also reported by Dwivedi [19] for aromatic rice cultivars. 
Biological Yield: The highest biological yield $\left(9.46 \mathrm{tha}^{-1}\right)$ was obtained from the variety Kachra and the lowest biological yield $\left(3.87 \mathrm{t} \mathrm{ha}^{-1}\right)$ was recorded from the variety Kalijira. From the result it was observed that biological yield differed due to combined effect of grain yield and straw yield. Plotting grain yield against biological yield (Fig. 7) gave a significant positive linear relationship which indicates that as biological yield increased, grain yield also increased.

Harvest Index: From the results presented in Table 1 it was found that harvest index do not follow any regular trend and was not significant due to variety. However, numerically the highest harvest index $(36.06 \%)$ was recorded from the variety Khaskani and the lowest $(25.48 \%)$ was calculated from the variety Kachra that means the variety Kachra is less efficient to translocate the assimilates towards the grain. Shah et al. [20]reported that variety had a great influence on harvest index.

\section{Conclusion}

From the above findings, it can be concluded that variation exists in different growth parameters and yield and yield contributing characters of selected aromatic rice cultivars. The variety Morichsail produced the highest grain yield compared to others which can be exploited through breeding.

\section{References}

[1] Das, T. and Baqui, M.A. 2000. Aromatic rices of Bangladesh. pp. 184-187. In: Singh, R.K.; Singh, U.S. and Khush, G.S. (eds.), Aromatic Rices. Oxford \& IBH Publishing Co. Pvt. Ltd., New Delhi and Calcutta, India.

[2] Baqui, M.A., Harun, M.E., Jones, D. and Straingfellow, R. 1997. The export potential of traditional varieties of rice from Bangladesh. Bangladesh Rice Research Institute, Gazipur, Bangladesh.

[3] Islam, M.R., Mustafi, B.A.A. and Hossain, M. 1996. Socio-economic aspects of fine quality rice cultivation in Bangladesh, In: Rice Research Prioritization, BRRI/IRRI.

[4] Alim, A., Zaman, S.M.H., Sen, J.L., Ullah, M.T. and Chowdhury, M.A. 1962. Review of half a century of rice research in East Pakistan. Agriculture Department, Government of East Pakistan, 33-63 pp.

[5] Gomez, K.A. and Gomez, A.A. 1984. Statistical Procedure for Agricultural research. $2^{\text {nd }}$ edition. John Wiley and Sons, New York. 680 p.

[6] Sawant, A.C., Throat, S.T., Khadse, R.R. and Bhosale, R.J. 1986. Response of early rice varieties to nitrogen levels and spacing in the coastal Maharashtra. Journal of Maharashtra Agricultural University. 11 (2): 182-184.

[7] Shamsuddin, A.M., Islam, M.A and Hossain, A. 1988. Comparative study on the yield and agronomic characters of nine cultivars of Aus rice. Bangladesh Journal of Agricultural Science, 15 (1): 121-124.

[8] Hossain, S.M.A., Alam, A.B.M.M. and Kashem, M.A. 1991. States of crop production technology. pp. 150-154. In: Fact searching and intervention in two FSRDP Sites Activities 1990-1991. Farming System Research and Development Programme, Bangladesh Agricultural University, Mymensingh.

[9] Khatun, R. 2001. Effect of variety and nitrogen on the performance of fine rice. M.Sc. Thesis, Department of Agronomy, Bangladesh Agricultural University, Mymensingh, Bangladesh, 93 p.

[10] Ramasamy, S., Chandrasekaran, B. and Sankaran, S. 1987. Effect of spacing and seedlings hill ${ }^{-1}$ on rice yield. International Rice Research Newsletter, Philippines, 12 (4): 49-54.

[11] Vergera, B.S., Lilis, R. and Tanaka, A. 1974. Relationship between the length of growing period and yield of rice plants under a limited nitrogen supply. Soil Science and Plant Nutrition, 10 (2): 15-21.

[12] Chowdhury, M.J.U., Sarkar, M.A.R. and Kashem, M.A. 1993. Effect of variety and number of seedlings hill ${ }^{-1}$ on the yield and yield components on late transplanted aman rice. Bangladesh Journal of Agricultural Science, 20 (2): 311-316.

[13] Anon. 1991. Annual Report. Bangladesh Rice Research Institute, Gazipur, Bangladesh, 300 p.

[14] Idris, M. and Matin, M.A. 1990. Response of four exotic strains of aman rice to urea. Bangladesh Journal of Agricultural Science, 17 (2): 271-275.

[15] Anon. 1993. Annual Report. Bangladesh Institute of Nuclear Agriculture (BINA), Mymensingh, 143 p.

[16] Anon. 1994. Annual Report. Bangladesh Rice Research Institute, Joydebpur, Gazipur, Bangladesh, 8-9 pp.

[17] Singh, S. and Gangwer, B. 1989. Comparative studies on production potentials in transitional tall and improved rice cultivars. Journal of Andaman Science Association, 5(1): 81-82.

[18] Sarkar, S.H. 2003. Yield and quality of fine rice varieties under early transplanting condition. M.Sc. Thesis, Department of Agronomy, Bangladesh Agricultural University, Mymensingh, Bangladesh, 90 p.

[19] Dwivedi, D. K. 1997. Response of scented rice (Oryza sativa) genotype of nitrogen under mid upland situation. Indian Journal of Agronomy, 43(1): 74-76.

[20] Shah, M.H., Khusu, M.K., Khande, B.A. and Bali, A.S. 1991. Effect of spacing and seedlings per hill on transplanted rice under late sown. Indian Journal of Agronomy, 36 (2): 274-275. 